\title{
Xylanase Purification of Indigenous Aspergillus tamari TKM-24 Isolated from Environmental Soil in Borneo Island
}

\author{
S Margino ${ }^{1}$, Y Mallisa $^{2}$, and W Asmara ${ }^{3}$ \\ ${ }^{1}$ Dept. of Microbiology, Faculty of Agriculture, Gadjah Mada University, Yogyakarta, \\ Indonesia. \\ ${ }^{2}$ Study Program of Biotechnology, Gadjah Mada University, Yogyakarta, Indonesia \\ ${ }^{3}$ Faculty of Veterinary Medicine, Gadjah Mada University, Yogyakarta, Indonesia \\ ${ }^{*}$ Corresponding author. Email: semargino@gmail.com
}

\begin{abstract}
Utilizing of chlorine-based chemicals in pulp bleaching process causes environmental problem. Utilization of biological agents, such as enzymes for bleaching process is a wise measure to reduce the problem. One of the enzymes that play an important role in pulp bleaching process is xylanase. The previous conducted research found out xylanolyitic fungi and determined for while as Aspergillus tamari TKM-24. The purpose of research was to purify xylanase enzyme t. The research methods were partial optimization of xylanase production and purification its xylanase Aspergillus tamari TKM-24. Partial optimization including environmental factors $(\mathrm{pH}$, agitation, temperature, airation), inoculum, substrate concentration, and time incubation. Purification steps of xylanase were precipitation by ammonium sulfate and gel filtration on sephadex G-75. Characterization of purified xylanase consisted of molecular weight, effect of $\mathrm{pH}$ and temperature to xylanase activity. The results showed that optimization of xylanase production was obtained by inoculum concentration $1 \%(\mathrm{v} / \mathrm{v})$, substrate xylan concentration $1 \%(\mathrm{w} / \mathrm{v}), \mathrm{pH} 5$ and incubation time for 4 days. Xylanase showed a single band on SDS PAGE analysis with a moleculer mass $25 \mathrm{kDa}$ and was purified 10,2 - fold by Spadex G-75. The Km and Vmax values were $24,4 \mathrm{mg} / \mathrm{ml}$ and $1520 \mu \mathrm{mol} / \mathrm{ml} / \mathrm{min}$ for oat spelt xylan, respectively. The Xylanase was clasified as termotolerant which had optimal temperature was around $55^{\circ} \mathrm{C}$ and $\mathrm{pH}$ value 6.0.
\end{abstract}

Keywords: Xylanase purification, Aspergillus tamari TKM-24.

\section{INTRODUCTION}

Pulping, bleaching, and papermaking are three major processing steps for producing pulp and paper. The kinds of pulp, paper raw material, desired quality of final product affecting by those process and most of them in the recent years involved chemicals and enzymes [1]. The regular procedure for paper making require high number of chemicals (chlorinated chemicals) which have environmental impact as pollution [2]. Most of the bleaching process for kraft pulp uses large amounts of chlorine-based chemicals and sodium hydrosulfite. Side effect of utilizing these chlorinated chemicals substances, some of which are toxic, mutagenic, persistent, bioaccumulate and cause harmful disturbances in biological systems
[3-4]. One of the ways to minimize chlorine based chemicals for pulping and bleaching process is xylanase enzyme utilization [5].

Interest in xylanolytic enzymes has incresed in the recent decades due to their potential apllication in industrial biotechnology and the last decade, one of the most studied and promising application of xylanase is in kraft pulp bleaching [6,7,8]. The major current industrial application of xylanases is in pulp and paper industry where xylanase pretreatment facilitates chemical bleaching of pulp. Utilizing of xylanases in the prebleaching of kraft pulps can reduce the amount of chlorine chemicals in the bleaching process and reduce the organochlorine in the effluent. Xylanase would act on the xylan precipitation from the lignin-causing the brown colour of pulp, thereby opening up the pulp structure to access by bleaching chemicals. However, it is also possible that xylanases release 
chromophores associated with carbohydrates. The cleavage of the carbohydrate portion of lignincarbohydrate complex to produce smaller residual lignin molecules, which are easier to remove, it is also a possible mechanism of xylanase prebleaching $[3,9,10]$.

The xylanase production has been reported for fungi [11-12], bacteria [13-14] and actinomycetes [15] and marine algae, protozoans, snails, crustaceans, insect, seeds [16], etc., but from microorganism is more interesting. Filamentous fungi are particularly interesting as xylanases producers due to these enzymes are extracellular, number and activities mostly higher than bacteria [9]. Preliminary isolation research from soil and saw dust around the forest in Borneo was found 92 xylan degrading isolates. Selection based on the xylanse specific activity found 8 isolates and one of them with higher xylanase activity and it was identified morphologically as Aspergillus tamari TKM-24. This selected isolate would be applied as a candidate for biopulping and biobleaching purpose.

The production of xylanases must be improved by finding more potent fungal to excrete greater amounts of xylanases. Therefore, the purpose of this study was to optimize partially xylanase production, purification of xylanase indigenous Aspergillus tamari KTM-24, and characterization of purified xylanase.

\section{MATERIALS AND METHODS}

\subsection{Material.}

Isolate of Aspergillus tamari KTM-24, idigenous of xylanolytic fungi isolated from Borneo island, Indonesia

\subsection{Methods}

\subsubsection{Partial optimization of xylanase production.}

The optimation of xylanase production was carried out in Mandels and Sternburg basal medium with oat spelt xylan as sole carbon source. Medium compositions (g/l) : $\left(\mathrm{NH}_{4}\right)_{2} \mathrm{SO}_{4}$ 1.4; $\mathrm{KH}_{2} \mathrm{PO}_{4}$ 2.0; urea $0.3 ; \mathrm{CaCl}_{2} 0.3 ; \mathrm{MgSO}_{4} .7 \mathrm{H}_{2} \mathrm{O} 0.3$ and $(\mathrm{mg} / \mathrm{l})$ of $\mathrm{FeSO}_{4} .7 \mathrm{H}_{2} \mathrm{O}$ 5.0; $\mathrm{MnSO}_{4} . \mathrm{H}_{2} \mathrm{O}$ 1.6; $\mathrm{ZnSO}_{4} .7 \mathrm{H}_{2} \mathrm{O}$ 1.4; $\mathrm{CoCl}_{2} 2.0$ and Tween $800.1 \%$ (v/v). Xylanase production was optimized by varying one dependent variable at a time, while all other parameters were kept constant. Variables include inoculum concentration, medium $\mathrm{pH}$, xylan concentration and incubation time. Optimization have been done gradually and for each steps was measured its xylanase activity and amount of protein.

\subsection{1.a. Inoculums concentration.}

Variations of inoculums concentration was used $5 \%, 7 \%$ and $10 \%(\mathrm{v} / \mathrm{v})$ containing $10^{7} / \mathrm{ml}$ spores. While other conditions were kept constant (xylan concentration $1 \%(\mathrm{w} / \mathrm{v})$; $\mathrm{pH}$ 5.6). The flasks were incubated at room temperature on a rotary shaker (100 rpm) for 5 days. Clear supernatant solutions obtained after centrifugation were assayed for xylanase activity and protein concentrations.

\subsection{1.b. Xylan concentration.}

In order to investigate the effect of s concentration on xylanase production, the s concentrations were used $0.5 \%, 1 \%$ and $1.5 \%$ $(\mathrm{w} / \mathrm{v})$. Inoculums concentration was used result of previous optimization. After incubation on a rotary shaker $(100 \mathrm{rpm})$ for 5 days, the culture broth was centrifuged, and the supernatants were collected for xylanase activity and protein assay.

\subsection{2.c. Initial pH medium.}

The effect of initial $\mathrm{pH}$ on xylanase production was optimized by vary $\mathrm{pH}$ within 4.0 to 9.0. Inoculums concentration and xylan concentration were used from the results of previous optimization. After incubation on a rotary shaker (100 rpm) for 5 days, the culture broth was centrifuged, and the supernatants were collected for xylanase activity and protein assay.

\subsection{1.d. Time of incubation.}

To evaluate the effect of time of incubation on xylanase production, the flasks were incubated at room temperature on a rotary shaker $(100 \mathrm{rpm})$ for 3 to 10 days. Clear supernatant solutions obtained after centrifugation were assayed for xylanase activity and protein concentrations.

\subsubsection{Xylanase Production.}

Xylanase enzyme production was done by applied results of previous experiments comprise inoculums concentration, xylan concentration, medium $\mathrm{pH}$ and incubation time. The culture broth was centrifuged at $5000 \mathrm{rpm}$ for $20 \mathrm{~min}$ at $4^{\circ} \mathrm{C}$. The supernatants were collected for xylanase activity and protein assay and used for the purification of enzymes.

\subsubsection{Purification of Xylanase.}

The purification of xylanase was carried out in two steps, that were ammonium sulphate precipitation and gel filtration chromatography. The calculated amount of solid ammonium sulphate was added to 
the culture supernatant at $4^{\circ} \mathrm{C}$ to achieve $20 \%$ saturation and left overnight. After centrifugation at $5000 \mathrm{rpm}$ for $45 \mathrm{~min}$, the precipitate was dissolved in a small volume of citrate buffer ( $50 \mathrm{mM}, \mathrm{pH} 5.0)$ and then the supernatant was adjusted to $40 \%$ saturation and continued until $80 \%$ saturation. The enzyme solution was subjected to dialysis for about $18-24$ hours at $4^{\circ} \mathrm{C}$ against $50 \mathrm{mM}$ citrate buffer ( $\mathrm{pH}$ 5.0) with three intermittent changes of the buffer. The protein solution was concentrated by freeze drying and applied on gel filtration column (Sephadex G-75) with elution of $50 \mathrm{mM}$ citrate buffer (pH 5.0). Fractions of $1.5 \mathrm{ml}$ were collected and assayed for xylanase activity. The protein content was determined spectrophotometrically at wave lenght $280 \mathrm{~nm}$. The highly xylanase activity fraction were used as purified enzyme for characterization.

\subsubsection{Biochemical characterization of the purified xylanases}

2.2.4.a. Molecular weight determination. The molecular weight of purified xylanase was estimated by sodium dodecyl sulfatepolyacrylamide gel electrophoresis (SDS-PAGE) used a $12 \%$ gel according to the method of Laemmli [17]. The protein were stained with $0.1 \%$ (w/v) Coomassie brilliant blue R-250.

2.2.4. b. Effect of $p H$ and temperature on xylanase activity. Oat spelt xylan $1 \%(\mathrm{w} / \mathrm{v})$ and purified enzyme solution were prepared in $50 \mathrm{mM}$ buffers at different $\mathrm{pHs}$. Citrate buffer used for $\mathrm{pH}$ 4-6 and phosphate buffer for $\mathrm{pH}$ 6.5-8. The effect of temperature on xylanase activity was determined in the range of $30^{\circ} \mathrm{C}$ to $80^{\circ} \mathrm{C}$ under standard assay conditions.

2.2.4. c. Kinetic parameters. The effect of oat spelt xylan concentration on xylanase activity was evaluated under optimal assay conditions. Diluted enzyme solution $(0.1 \mathrm{ml})$ was incubated with $0.9 \mathrm{ml}$ of various concentrations $(2.5,5.0,7.5,10,15$ $\mathrm{mg} / \mathrm{ml}$ ) of oat spelt xylan in $50 \mathrm{mM}$ citrate buffer for 1-10 min. Xylanase activity was assayed as described above. The kinetic parameters (Michaelis-Menten constant, $\mathrm{Km}$ and maximal reaction velocity, Vmax) were estimated by linear regression from double-reciprocal plots according to Lineweaver and Burk.

\subsubsection{Enzyme assay, carbohydrate and protein determination.}

Xylanase activity was determined by mixing $0.9 \mathrm{ml}$ of $1 \%(\mathrm{w} / \mathrm{v})$ oat spelt xylan (prepared in $50 \mathrm{mM}$ citrate buffer, $\mathrm{pH} 5.0$ ) with $0.1 \mathrm{ml}$ of suitably diluted enzyme and the mixture was incubated at $50^{\circ} \mathrm{C}$ for $30 \mathrm{~min}$ (Bailey et al., 1992 [18)]. The reaction was stopped by addition of $1.0 \mathrm{ml}$ of 3,5dinitrosalicylic acid (DNS) and boiled for $5 \mathrm{~min}$. After cooling, the developed colour was read using spectrophotometre at $540 \mathrm{~nm}$. The amount of liberated reducing sugar was quantified using xylose as standard. One unit of xylanase was defined as amount of enzyme required to release 1 $\mu$ mol of xylose from oat spelt xylan in one minute under the standard assay conditions. Protein concentration were measured according to Bradford [(197619]) method using bovine serum albumin as a standard.

\section{RESULTS AND DISCUSSION}

Results and discussion will show the results of partial optimization of Aspergillus tamari KTM-24 which grown on the concentration of inoculum, xylan substrate, and the effect of environment factors like $\mathrm{pH}$, temperature and time course; enzyme purification and chracterization of pured enzyme

3.1. Partial optimization. Partial optimization of Xylanase Production consist of inoculum concentration, substrate xylan concentration, initial $\mathrm{pH}$ effect, and time course

\section{1.a. Inoculum concentration.}

To evaluate for xylanase production, inoculums concentration were used $5 \%, 7 \%$ and $10 \%(\mathrm{v} / \mathrm{v})$ containing $10^{7} / \mathrm{ml}$ spores. Based on the xylanase activity, the various of inoculums concentration influenced for xylanase production which showed the different of xylanase activity in various of inoculums concentration. The highest xylanase activity was obtained in $10 \%$ inoculums concentration, corresponding to the value 496.30 $\mathrm{U} / \mathrm{ml}$ (Figure 1). 


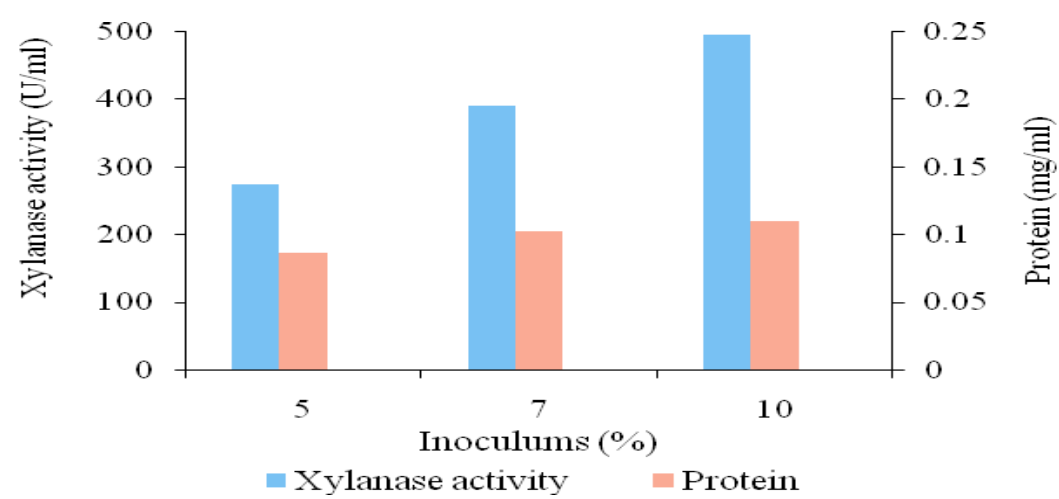

Figure 1. Effect of inoculums concentration on xylanase production by Aspergillus tamarii TKM-24

Influence of inoculums concentration associated with the growth of fungal in medium for xylanase production. However, appropriate of inoculums required for assimilation of carbon source to enzyme production. The high of inoculums concentration caused a decrease in the specific velocity of oxygen consumption. In both cases, this could be affected for enzyme production [20].
Based on the result, the highest level of xylanase was found in $10 \%$ inoculums concentration.

3.1.b. Xylan concentration. Different xylan concentration $(0.5 \%, 1.0 \%$ and $1.5 \%(\mathrm{w} / \mathrm{v}))$ were tested for xylanase production. The result showed that the highest of xylanase activity was obtained in $1 \%$ xylan concentration $(547.70 \mathrm{U} / \mathrm{ml})$. Data depicted at Figure 2

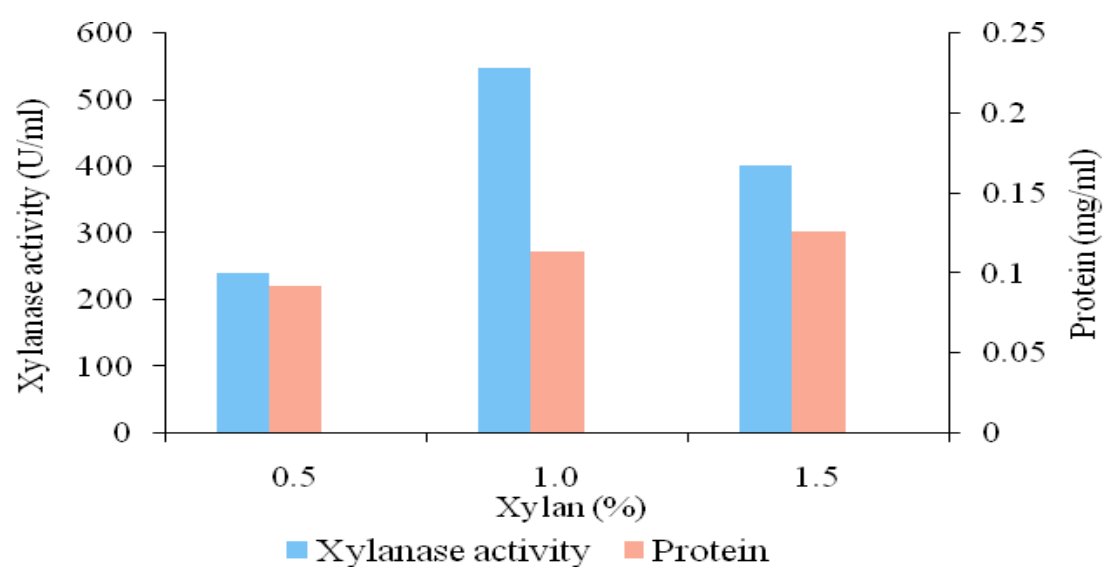

Figure 2. Effect of xylan concentration on xylanase production by Aspergillus tamarii TKM-24

The production of xylanase was reached the highest level when $1 \%$ of oat spelt xylan was added. Increasing the concentration for more than $1 \%$ resulted a significant decrease of level xylanase. The mechanisms that govern the formation of extracellular enzymes are influenced by the availability of inducer for protein synthesis. Xylan was known a good inducer for xylanase production. Hence the concentration of inducer in the culture filtrate also effect the xylanase synthesis [10]. 3.1.c. Initial $p H$ medium. Productivity of the enzyme by fungus is very specific to the $\mathrm{pH}$ of the medium. The production of xylanase by Aspergillus tamarii TKM-24 was studied by varying the initial $\mathrm{pH}$ of the fermentation media from 4 to 9 (figure 3). The maximum production of xylanase (696.65 $\mathrm{U} / \mathrm{ml}$ ) was achieved when the initial $\mathrm{pH} 5$ of medium. When the $\mathrm{pH}$ was increased or decreased from the optimum value, the production of xylanase was greatly decreased. It was because the organism required slightly acidic $\mathrm{pH}$ for the growth as well as enzyme production. 
On the other hand, alkaline $\mathrm{pH}$ had inhibitory effect on the growth of Aspergillus tamarii TKM-

24 and influenced of xylanase production

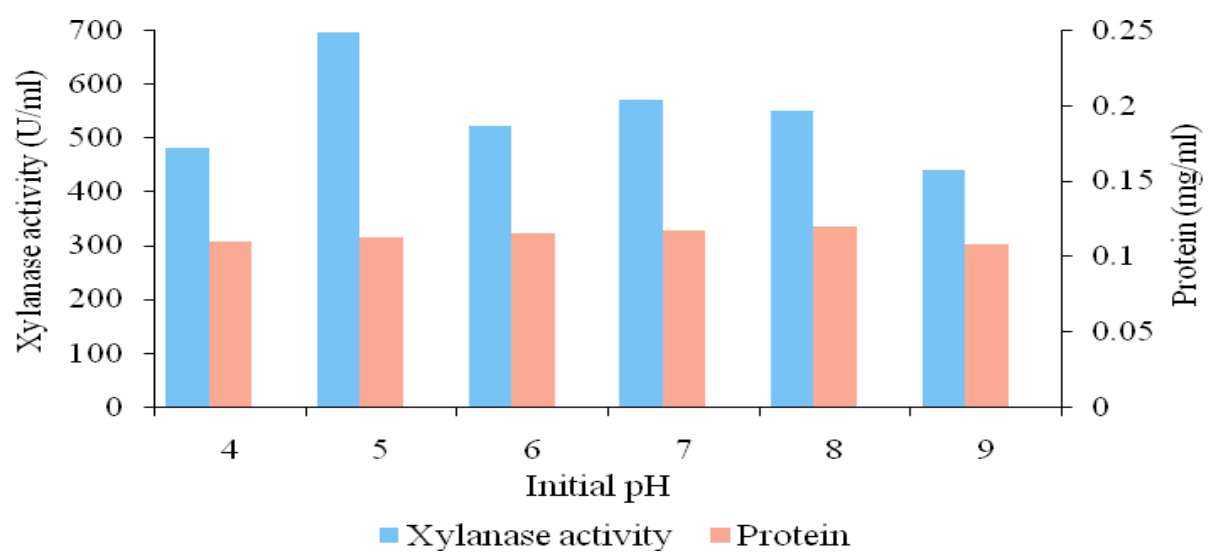

Figure 3. Effect of initial $\mathrm{pH}$ of medium on xylanase production by Aspergillus tamarii TKM-24

Initial $\mathrm{pH}$ medium plays a critical role in enzyme productivity. The $\mathrm{pH}$ influences the transport of several species of enzyme across the cell membrane. In addition, cultivation of fungi at an unfavourable $\mathrm{pH}$ value may favour limited growth rate and xylanase production by reducing accessibility of the substrate. Fermentation at lower and higher $\mathrm{pH}$ proved to be detrimental, perhaps because of the inactivation of the enzyme system [21-22]. 3.1.d. Incubation timel time course. The time course of xylanase production by Aspergillus tamarii TKM-24 was further investigated (figure 4). Xylanase production increased from 3 days to 5 days. The result showed maximum xylanase production was achieved after 5 days incubation (720.25 U/ml). Further incubation after 5 days did not show any increment in the level of xylanase production. The reduction of xylanase production was probably due to the depletion of nutrients available to fungus

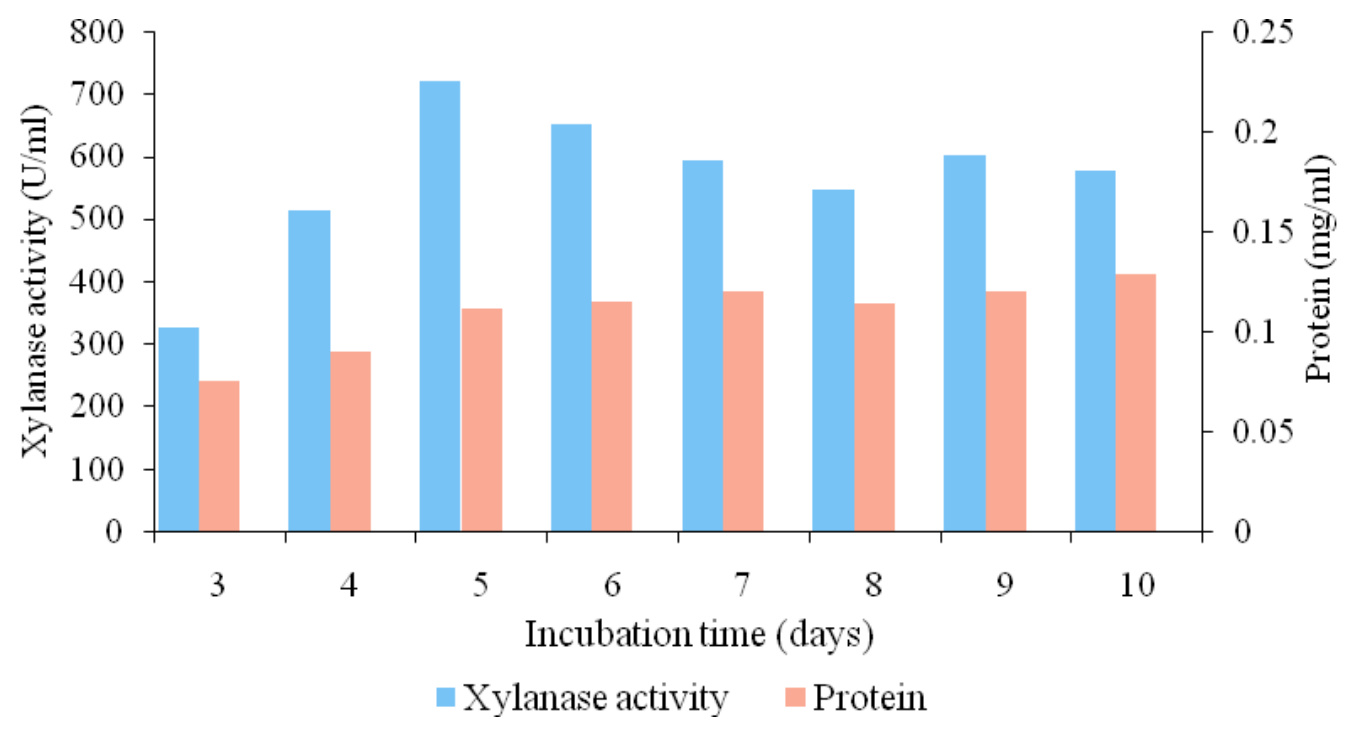

Figure 4. Effect of incubation time on xylanase production by Aspergillus tamarii TKM-24

The time of incubation are influences to xylanase production. Xylanase being primary metabolites are optimally expressed at the exponential phase, which correlates the harvesting time of the fungus to the xylanase production. Metabolic enzymes like, proteases and transglycosidases might also affect xylanase yield [11]. 


\subsection{Purification of Xylanase}

The results of the purification of extracellular xylanase produced by Aspergillus tamarii TKM-24 is summarized in Tabel 3. The first step in purification was convectional $(\mathrm{NH} 4)_{2} \mathrm{SO}_{4}$ precipitation. The precipitation by $60 \%$ saturation of ammonium sulphate reveal maximum enzyme specific activity (23140. $97 \mathrm{U} / \mathrm{ml} / \mathrm{mg}$ protein) and purification fold was 3.12 , and 17.95 recovery xylanase activity, data was shown at Table 1 .

Table 1. Ammonium sulphate precipitation of xylanase Aspergillus tamarii TKM-24

\begin{tabular}{lccccc}
\hline \multicolumn{1}{c}{ Steps } & $\begin{array}{c}\text { Total activity } \\
(\mathrm{U})\end{array}$ & $\begin{array}{c}\text { Total Protein } \\
(\mathrm{mg})\end{array}$ & $\begin{array}{c}\text { Specific activity } \\
(\mathrm{U} / \mathrm{mg})\end{array}$ & $\begin{array}{c}\text { Yield } \\
(\%)\end{array}$ & $\begin{array}{c}\text { Purification } \\
(\text { fold })\end{array}$ \\
\hline Crude extract & 321316.80 & 43.26 & 7427.57 & 100 & 1 \\
$(\mathrm{NH} 4)_{2} \mathrm{SO}_{4}(0-20 \%)$ & 22162.14 & 1.61 & 13765.30 & 6.90 & 1.85 \\
$(\mathrm{NH} 4)_{2} \mathrm{SO}_{4}(20-40 \%)$ & 28816.72 & 1.72 & 16753.91 & 8.97 & 2.26 \\
$(\mathrm{NH} 4)_{2} \mathrm{SO}_{4}(40-60 \%)$ & 57690.45 & 2.49 & 23140.97 & 17.95 & 3.12 \\
\hline
\end{tabular}

The precipitate of xylanase was subjected to dialysis step (data unshown) and further more for purification on the Sephadex G-75 gel filtration chromatography. The results of protein content which was measured by spectrophotometric analyzing on the wave lenght at $280 \mathrm{~nm}$ and xylanase activity were showed at figure 5. Elution profile showed that two peaks of protein profile but only one peak of xylanase activity was observed in the gel filtration (Figure 6). The high of xylanase activity was found out in the first peak (fraction 2830) and highest in 29 fraction.

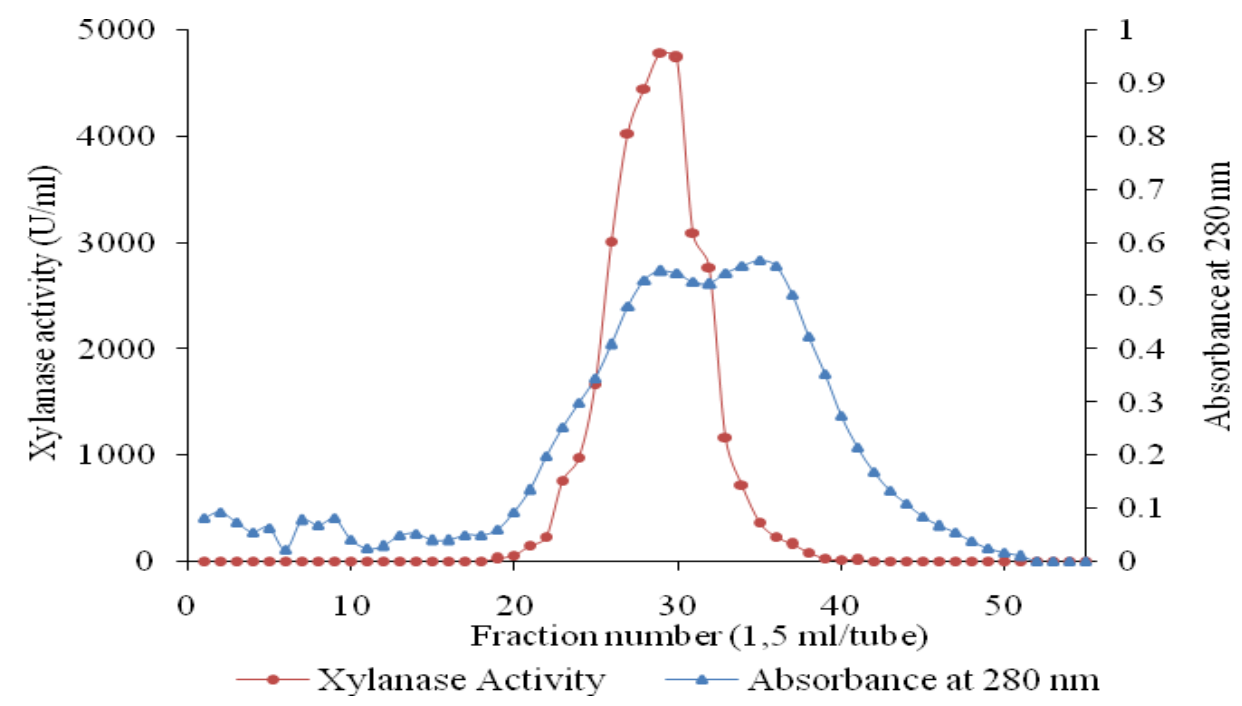

Figure 5. Elution profile of the xylanase activity and protein produced by Aspergillus tamarii TKM-24 on Sephadex G-75.

The specific activity was increased after purification by ammonium sulfat and gel filtration. Result of the final purification step the enzyme was purified 10.19 fold purification with $75671.88 \mathrm{U} / \mathrm{mg}$ specific activities and $2.32 \%$ activity recovery. Fraction with highest activity was used to characterization of xylanase properties. The results of xylanase purification are summarised in Table 2 . 
Table 2. The purification steps of xylanase of Aspergillus tamarii TKM-24

\begin{tabular}{lccccc}
\hline \multicolumn{1}{c}{ Steps } & $\begin{array}{c}\text { Total } \\
\text { activity }(\mathrm{U})\end{array}$ & $\begin{array}{c}\text { Total Protein } \\
(\mathrm{mg})\end{array}$ & $\begin{array}{c}\text { Specific activity } \\
(\mathrm{U} / \mathrm{mg})\end{array}$ & $\begin{array}{c}\text { Yield } \\
(\%)\end{array}$ & $\begin{array}{c}\text { Purification } \\
(\text { fold })\end{array}$ \\
\hline Crude extract & 321316.80 & 43.26 & 7427.57 & 100 & 1 \\
$(\mathrm{NH} 4)_{2} \mathrm{SO}_{4}(40-60 \%)$ & 57690.45 & 2.49 & 23168.85 & 18.0 & 3.12 \\
Sephadex G-75 & 7264.50 & 0.096 & 75671.88 & 2.32 & 10.19 \\
\hline
\end{tabular}

3.3. Characterzation ofxylanase. Characterization of xylanase comprise of molecular weight determination, effect $\mathrm{pH}$ and temperature on xylanase activity

\section{3.a.Molecular weight determination}

The purified xylanase showed a single band on SDSPAGE when stained with Coomassie Brilliant Blue (figure 6) showed that the xylanase of Aspergillus tamarii TKM-24 reveal one band which illustrated a monomeric protein and only one form. The molecular mass of the xylanase of Aspergillus tamarii TKM-24 was estimated to be $25.0 \mathrm{kDa}$, which was similar to the molecular mass of the xylanase of Penicillium sp. $40(25 \mathrm{kDa})[23]$ and Aspergillus giganteus CCT 3232 [24]. Other researcher showed that Aspergillus terreus had a molecular mass $23 \mathrm{kDa}$ [25]) and Penicillium gabrum had molecular mass $18.36 \mathrm{kDa}[6]$.

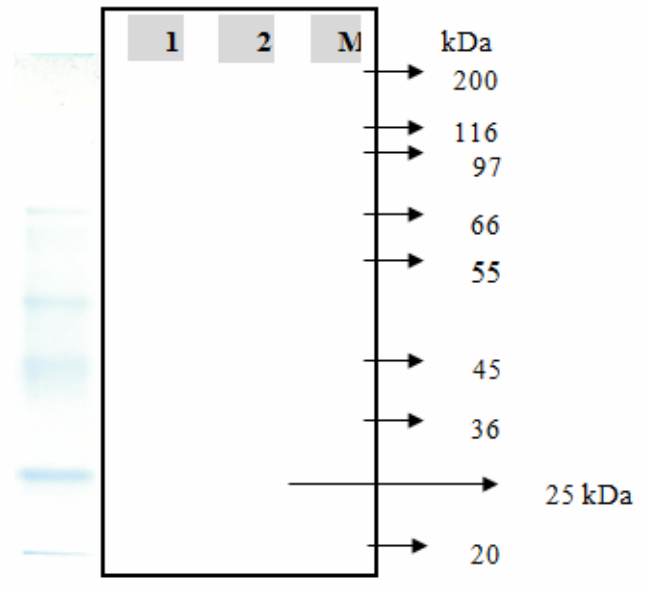

Figure 6. SDS-PAGE of extracellular enzymes from Aspergillus tamarii TKM-24.

L1: Precipitation by ammonium sulphate, L2: Sephadex G-75 (fraction number 29), M: Protein marker (Wide Range Sigma Marker 20-200 kDa). In the application of xylanase as bleaching agents in pulp and paper industry are desirable low molecular weight, since they can easily penetrate into the reprecipitated xylan on the surface of kraft pulp.

\section{3.b. Effect of $p H$ and temperature on xylanase activity}

The purified of xylanase from Aspergillus tamarii TKM-24 was active between $\mathrm{pH} 4.0-8.0$. The
This alleviates the problem of xylan barrier on the surface of lignin containing pulp during subsequent chemical bleaching steps [26].

optimal of xylanase activity was achieved at $\mathrm{pH} 6$ (figure 7). Similar to Aspergillus terreus UL4209, A. oryzae NRRL1808 and Penicillium oxalicum ZH-30 exhibited optimal at $\mathrm{pH} 6$ [27-29]. A significant decrease enzyme activity was observed at below and above the optimal $\mathrm{pH}$. 


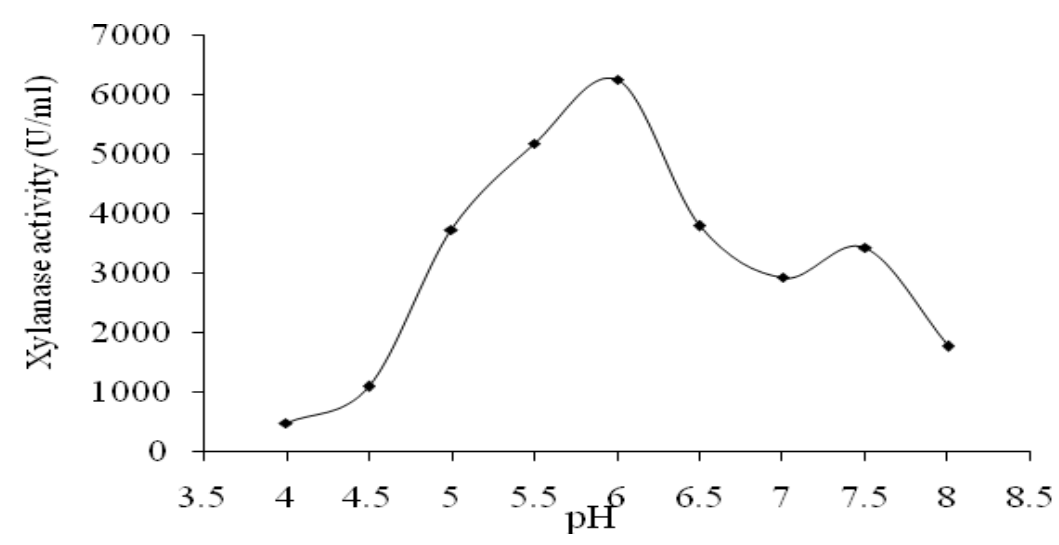

Figure 7. Effect of $\mathrm{pH}$ on xylanase activity from Aspergillus tamarii TKM-24

Aspergillus tamarii TKM-24 xylanase showed the optimal temperature at $60^{\circ} \mathrm{C}$. A significant decrease enzyme activity was observed below and above the optimal temperature, and loss of enzyme activity at $80^{\circ} \mathrm{C}$ (figure 8). Xylanase of Aspergillus terreus had optimal temperature at $50^{\circ} \mathrm{C}$ [25], Trichoderma inhantum stable at $40^{\circ} \mathrm{C}$ [11], T. harzianum had optimal temperature at $60{ }^{\circ} \quad \mathrm{C} \quad[30]$ and Chrysoporthe cubensis $\mathrm{P} 2$ better performance at $55^{\circ} \mathrm{C}$

[31].

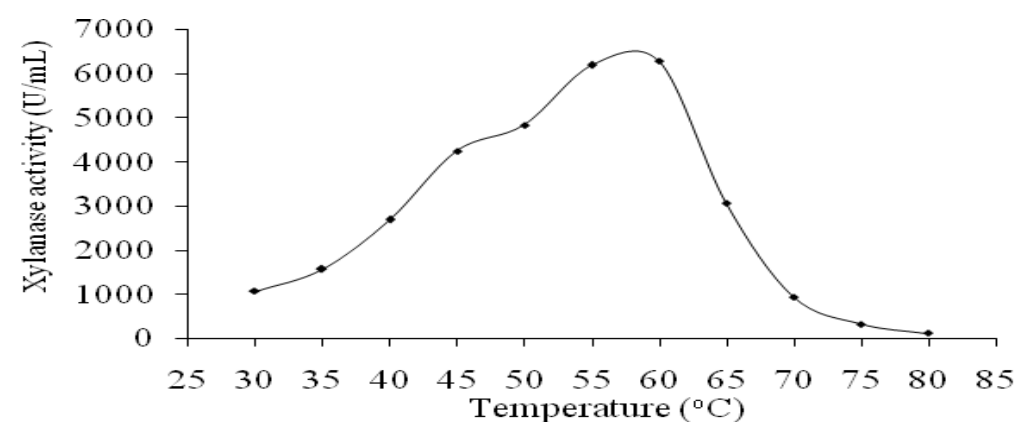

Figure 8. Effect of temperature on xylanase activity from Aspergillus tamarii TKM-24

Enzyme activity is markedly affected by $\mathrm{pH}$, because substrate binding and catalysis are often dependent on charge distribution on both substrate and in particular enzyme molecules. Enzymes are liable to denaturation under harsh conditions by $\mathrm{pH}$ change and high temperature, with adverse effects on their activities site resulting in a subsequent loss of enzyme activity [22].

\section{3.c. Kinetic parameters}

The determination of $K_{m}$ and $v_{\max }$ values was based on the optimum $\mathrm{pH}$ and temperatures condition. The xylanase from Aspergillus tamarii TKM-24 was exhibited $K_{m}$ and $v_{\max }$ values of $24.4 \mathrm{mg} / \mathrm{ml}$ and $1520 \mu \mathrm{mol} / \mathrm{ml} / \mathrm{min}$ for oat spelt xylan by Lineweaver-Burk plot (figure 9). 


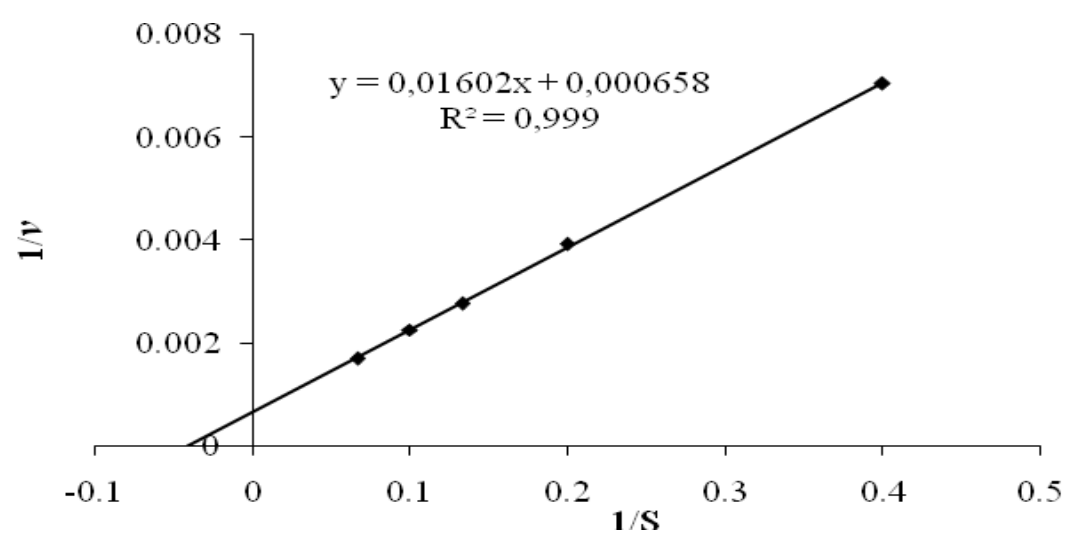

Figure 9. Lineweaver-Burk plot of xylanase from Aspergillus tamarii TKM-24

The $v_{\max } / K_{m}$ ratio known to be more significant parameter with respect to catalytic efficiency [32]. The $v_{\max } / K_{m}$ ratio of xylanase from Aspergillus tamarii TKM-24 was exhibited 62.3 values, that indicated high catalytic efficiency to substrates. The high of $v_{\max }$ values also showed ability to hydrolyze substrates.

\section{CONCLUSIONS}

Aspergillus tamarii TKM-24 indigenous Indonesia produced high xylanase activity on the oat spelt xylan substrate. Partial optimization of xylanase production was achieved by inoculums concentration $1 \%(\mathrm{v} / \mathrm{v})$, xylan concentration $1 \%$ $(\mathrm{w} / \mathrm{v})$, initial $\mathrm{pH} 5$ and incubation for 5 days. The purification results showed that purified xylanase increased 10.19 fold after precipitation by ammonium sulphate and Sephadex G-75 gel filtration chromathography. The molecular mass of the Aspergillus tamarii TKM-24 xylanase was 25 $\mathrm{kDa}$; optimal temperature activity at $60{ }^{\circ} \mathrm{C} ; \mathrm{pH} 6$; $K_{\mathrm{m}}$ and $v_{\max }$ were $24.4 \mathrm{mg} / \mathrm{ml}$ and 1520 $\mu \mathrm{mol} / \mathrm{ml} / \mathrm{min}$ for oat spelt xylan.

\section{REFERENCES}

[1] Lopez, A.N.Q., A.L. Silva and C.L. Santos. 2017. The fungal ability for bleaching/ pulping/bioremidiation of lignin-like compounds of agro-industrial raw material. Quim. Nova. Vol 40(8):916-931

[2] Verma, D., and T. Satyanarayana. 2013. Production of cellulase-free xylanase by recombinan Bacillus subtilis and its applicability in paper pulp bleaching. Biotechnol. Prog. doi: 10.1002/btpr.1826
[3] Singh, P., O. Sulaiman, R. Hashim, P.F. Rupani and L.C. Peng. 2010. Biopulping of lignocellulosic material using different fungal species: a review. Rev. Environ. Sci. Biotechnol. 9:141-151

[4] Pastor, F. I. J., O. Gallardo, J. Sanz-Aparicio dan P. Diaz. 2007. Xylanases: Molecular Properties and Applications. Dalam. Industrial Enzymes: Structure, Function and Applications (J. Polaina dan A. P. MacCabe., Eds.). Springer. The Netherlands. p: 65-78.

[5] Walia, A., P. Mehta, and S.C.K. Shirkot. 2015. Modification in the properties of paper by using cellulase-free xylanase produced from alkalophilic Cellulosimicrobium cellulans CKMXI in biobleaching of wheat straw pulp. Can. J. Microbiol 61:1-11

[6] Knob,A., S.M. Beitel, D. Fortkamp, C.R.F. Terassan and A.F. de Almeida. 2013. Production and purification, and chracterization of a major Penicellium glabrum xylanase using Brewer's spent grain as substrate. BioMed Res. International Volume.2013

[7] Peixoto-Nogueira, S.C., M. Michelin, J.H. Betini, J.A. Jorge, H.F. Terrezi, and MLTM. Polizeli. 2009. Production of xylanase by Aspergilli using alternative carbon source: application of he crude extract on sellulose pulp bleaching. J.Ind Microbiol. Biot. 36(1):149-155

[8] Michelin M., S.C. Peixoto-Ngueira, J.H. Betini, T.M. da Silva, J.A. Jorge, H.F.Terenzi, and MLTM. Polizeli. 2010. Production and properties of xylanase from Aspergillus terricola Marchal and Aspergillus ochraceus and their use in cellulose pulp bleaching. Biosyst Eng. 
33(7):813-821

[9] Walia, A., S. Guleria, P. Mehta,A. Chauman, and J.Parkash. 2017. Microbial xylanase and their industrial application in pulp and paper biobleaching: a review. 3 Biotech.3:7-11

[10] Polizeli, M.L.T.M., A.C.S. Rizzatti, R. Monti, H.F. Terenzi, J.S. Jorge dan D.S. Amori. 2005. Xylanases from fungi: properties and industrial applications. Appl. Microbiol. Biotechnol. 67: 577-591

[11] Silva,L.A.O., C.R.F. Terrassan and E.C. carmona. 2015. Purification chracterization of xylanase from Trichoderma inhamatum. Electric J. of Botechnol. 18:307-313

[12] Oyedeji.O., A. Iluyomade, I. Egbewumi and A. Oduwufa. 2018. Isolation and screening of xylanolytic fungi from soil of Botanical garden: Xylanase production fron Aspergillus flavus and Trichoderma viride. J. Microbiol. Res. 8(1):9-18

[13] Sepahy, AA., S. Ghazi, and M.A. Sepahy. 2011.Cost effective production and optimization of alkaline xylanase by Bacillus mojavensis AG137 fermented on agricultural waste. Enzyme Res. 6:593-624

[14] Garg, G., R. Mahajan, A. Kaur and J. Sharma. 2011. Xylanase production using agro-residue in solid-state fermentation from Bacillus pumillus ASH for biolignification of wheat straw pulp. Biodegradation 22(6):1143-1154

[15] Rahmani, N., P. Apriliana, A.M. Jannah, P. Lisdiyanti, E. Hermiati, B. Prasetyo and Yopi. 2018. 2nd International Conference on National Products and Bioresource Sciences2018. IOP Conf. Series: Earth and Environmental Science 251 (2019) 012053

[16] Sipriyadi, Y. Lestari, A.T. Wahyudi, A. Meryandini, and M.T. Suhartono. 2016. Exploration of potential Actinomycetes CIFRO Forest Original as antimivrobial, antifungus, and producing xylanase. Biosaintifika 8(1):96-104

[17] Laemmli, U. K. 1970. Cleavage of structural proteins during the assembly of the head of bacteriophage T4. Nature 227: 680-685.

[18] Bailey, M.J., P. Biely and K. Poutanen. 1992. Interlaboratory testing of methods for assay of xylanase activity. J. Biotechnol. 23: 257-270.

[19] Bradford, M.M., 1976. A rapid dan sensitive method for the quantitation of microgram quantities of protein utilizing the principle of protein dye binding. Anal. Biochem. 72: 248254.

[20] Simões, M.L.G., S.M.T. Tornisielo, D.M.T. Tapia. 2009. Screening of culture condition for xylanase production by filamentous fungi. Afr. J. Biotechnol. 8: 6317-6326.
[21] Bakri, Y., M. Jawhar dan M.I.E. Arabi. 2008. Improvement of Xylanase Production by Cochliobolus sativus in Submerged Culture. Food Technol. Biotechnol. 46 (1): 116-118.

[22] Kaur, H., D. Dutt and C.H. Tyagi. 2011. Production of novel alkali-thermo-tolerant cellulase-poor xylanase from Coprinopsis cinerea HK-1 NFCCI-2032. BioResour. 6(2): 1376-1391.

[23] Kimura, T., J. Ito, A. Kawano, T. Makino, H. Kondo, S. Karita, K. Sakka and K. Ohmiya. 2000. Purification, characterization, and molecular cloning of acidophilic xylanase from Penicillium sp. 40. Biosci. Biotechnol. Biochem. 64: 1230-1237.

[24] Fialho, M.B dan E.C. Carmona. 2004. Purification and characterization of xylanases from Aspergillus giganteus. Folia Microbiol. 49: 13-18.

[25] Sargatto, M., N.C.A. Guimaraes, F.F. Zanoelo, M.R. Marques, S.C. PeixotoNogueira and G.G. Giannesi. 2012. Purification and characterization of an extracellular xylanase produced by the endophytic fungus, Aspergillus terreus, grown in submerged fermentation. African $J$. Biotechnol. 11(32):8076-8084

[26] Ninawe, S., M. Kapoor, and R.C. Kuhad. 2008. Purification and characterization of extracellular xylanase from Streptomyces cyaneus SN32. Bioresour. Technol. 99: 12521258.

[27] Chidi, S.B., B. Godana, I. Ncube, E.J.V. Rensburg, A. Cronshaw and E.K. Abotsi. 2008. Production, purification and characterization of celullase-free xylanase from Aspergillus terreus UL 4209. Afr. J. Biotechnol. 7: 3939-3948.

[28] Szendefy,J., G. Szakacs and L. Christopher. 2006. Potential of solid-state fermetation enzymes of Aspergillus oryzae in bioblaching of paper pulp. Enzyme Microb. Technol. 39:1354-1360

[29] Li, Y., Z.Liu, F. Cui, Y.Y Xu and H. Zhao. 2007. Production of xylanase from a newly isolated Penicillium sp. ZH-30. World J. Microbiol. Biotechnol. 23: 837-843.

[30] Isil, S., and A. Nilufer. 2005. Investigation of factors affecting xylanase activity Trichoderma harzianum 1073 D3. B Arch. Biol. Technol. 48: 187-193.

[31] Gomes,K.S., G.P.M. Alfenas, L.G.Anuмu, D.L. Falkoski, A.C. Alfenas, S.T. Rezende. 2017. Purification and characterization of xylanase from the fungus Chrysoporthe cubensis for production of 
xylooligosaccharaides and fermentable sugars. Appl. Biochem. Biotechnol. 182:818-830

[32] Faulet, B. M., S. Niamke, J. T. Gonnety, and L. P. Kouame. 2006. Purification and biochemical properties of a new thermostable xylanase from symbiotic fungus, Termitomyces sp. Afr. J. Biotechnol. 5: 273282. 